\title{
UPAYA MINIMALISASI DAMPAK PENCEMARAN DARI LIMBAH LEMURU SEBAGAI BAHAN BAKU NATA DE FISH DI KECAMATAN MUNCAR KABUPATEN BANYUWANGI
}

\author{
Oleh \\ Nadya Adharani, Any Kurniawati, Sulistiono, Megandhi Gusti Wardhana \\ Program Studi IImu Perikanan. Universitas PGRI Banyuwangi, Banyuwangi \\ Jawa Timur \\ Email: nadya.adharani@gmail.com \\ Received February 2017, Accepted March 2017
}

\begin{abstract}
ABSTRAK
Ikan lemuru (Sardinella longiceps) merupakan primadona bagi daerah Banyuwangi khususnya di Kecamatan Muncar. Potensi ikan lemuru yang cukup banyak dimanfaatkan menjadi olahan produk makanan bagi perusahaan yang berdiri di sekitaran Kecamatan Muncar. Mengingat kandungan protein yang cukup tinggi didalam limbah ikan lemuru yang berasal dari buangan limbah perusahaan, maka penelitian ini bertujuan untuk memanfaatkan limbah lemuru sebagai bahan baku nata de fish sebagai upaya meminimalisir dampak pencemaran. Sebanyak 4 perlakuan dilakukan dalam menentukan formulasi nata de fish, P2.C merupakan perlakuan terbaik karena menghasilkan nata de fish hingga $980 \mathrm{gr}$, dengan hasil kandungan proksimat (karbohidrat, protein, lemak, serat, nitrogen, mineral) yang lebih baik dibandingkan nata de coco. Selain meminimalisasi dampak pencemaran, nata de fish merupakan kreativitas olahan produk perikanan di Banyuwangi.
\end{abstract}

Kata kunci : Nata de fish, ikan lemuru, pencemaran, Kecamatan Muncar

\begin{abstract}
Lemuru (Sardinella longiceps) is primadonna in Banyuwangi area especially at district muncar. Lemuru has high potential as raw material in food industries in Muncar, Banyuwangi. Waste of lamuru industries have high protein content, the ami of this study was to used the waste of lamuru as raw material of nata de fish, and to minimized the impact of the pollution. Tottaly, 4 treatment were done in this study. P2. C was the best treatment, it produced nata de fish more than $980 \mathrm{gr}$. The proksimat contents such carbohydrates, protein, fat, fiber, nitrogen, minerals of P2.C were better than the nata de coco. In addition to minimized the impacts of pollution, nata de fish was kind of creativity of fisheries products in Banyuwangi.
\end{abstract}

Keywords : Nata de fish, lemuru, pollution, Muncar 


\section{PENDAHULUAN}

Kecamatan Muncar merupakan daerah sebagai bandar ikan laut terebesar kedua setelah Kecamatan Bagansiapiapi di Jawa timur. Rata-rata mata pencaharian masyarakat adalah sebagai nelayan, pembudidaya dan memanfaatkan potensi perikanan, salah satu ikan laut yang berpotensi adalah ikan lemuru (Sardinella longiceps). Bahkan ditemui beberapa industry modern (pengalengan ikan, cold storage dan industri tepung dan minyak ikan) memanfaatkan ikan lemuru sebagai bahan baku utama industri. Kelompok industr tradisional pun (home industry) memanfaatkan lemuru untuk dijadikan ikan es-esan, petis, terasi, pemindangan dan pengasinan (Purwaningsih, 2015).

Meski nilai ekonomis ikan lemuru rendah namun perannya terhadap keseimbangan ekologi bagi perikanan Selat Bali cukup penting sebagai ikan demersal dengan stok terbanyak. Sekitar $70 \%-80 \%$ produksi perikanan Selat Bali adalah Lemuru (BPPI Muncar, 2009), maka pengaruh perikanan Lemuru terhadap ekonomi nelayan dan industri pengolahan ikan di Muncar maupun pengambengan menjadi penting.

Priambodo (2011) mengatakan Kecamatan Muncar Kabupaten Banyuwangi adalah sentra penghasil ikan terbesar di Jawa Timur dengan jumlah produksi ikan tahun 2011 sebesar 27.748 ton dan jumlah limbah cair yang dihasilkan oleh seluruh industri pengolahan ikan di Muncar mencapai $14.266 \mathrm{~m}^{3}$ setiap harinya. Industri pengolahan ikan tentunya memberikan kontribusi besar bagi pencemaran sungai setempat, karena sejumlah industri pengolahan ikan yang ada di daerah Muncar belum menjalankan Instalasi Pengolahan Air Limbah (IPAL) dengan baik. Akibat dari hal tersebut beberapa bahan pencemar dan parameter kualitas air yang terdapat di sungai di sekitar kawasan industri pengolahan ikan telah jauh melebihi kadar baku mutu kualitas air yang ditetapkan oleh pemerintah (Priambodo, 2011).

Pemanfaatan limbah cair pengalengan ikan sebagai produk yang bermanfaat dan ekonomis merupakan upaya pendukung prinsip blue economy. Salah satu jenis produk terbarukan yang dapat dihasilkan melalui home industry adalah nata de fish, nata de fish adalah nata yang dihasilkan dari sari ikan (limbah industri ikan). Faktor pendukung dari proses pembuatan nata de fish ialah limbah cair berupa hasil rebusan pengalengan ikan yang didalamnya terkandung protein, dimana protein tersebut mendukung pertumbuhan bakteri Acetobacter xylinum, guna proses fermentasi pembuatan nata.

Nata merupakan selulosa hasil fermentasi bakteri $A$. xylinum yang mengandung lebih kurang 98\% konsistensinya kokoh dan teksturnya kenyal (Pambayun, 2002). Pembentukan nata terjadi karena pemanfaatan glukosa dari gula oleh sel A.xylinum. A. xylinum akan membentuk nata jika tumbuh pada substrat yang kaya karbon $(\mathrm{C})$ dan nitrogen $(\mathrm{N})$ melalui proses fermentasi yang terkontrol. A. xylinum akan menghasilkan jutaan selulosa yang disebut sebagai serat nata. Pembuatan nata tidak hanya dari air kelapa, namun dari beberapa bahan makanan yang mengandung gula, protein, dan mineral. Begitupun, pembuatan nata dapat dilakukan dari air limbah perebusan ikan lemuru, hal tersebut dilakukan karena diduga limbah hasil rebusan ikan lemuru masih 
terkandung protein. Penjelasan diatas mengindikasikan bahwa limbah ikan lemuru berpotensi sebagai media pembuatan nata de fish, sehingga diharapkan dapat mengurangi bahan pencemar limbah yang dikeluarkan di kawasan industry kecamatan Muncar, sehingga pemanfaatan limbah akan menjadi tambahan nilai ekonomis bagi masyrakat Kabupaten Banyuwangi.

\section{MATERI DAN METODE}

\section{Sampel Limbah Lemuru}

Limbah lemuru diambil dari PT. Maya Muncar Kecamatan Muncar Banyuwangi. Menurut informasi yang didapat dari perusahaan, bahwa setiap harinya PT. Maya Muncar menghasilkan limbah cair sebanyak $200 \mathrm{~m}^{3}$ dari hasil produksi kurang lebih 20 ton ikan lemuru, oleh sebab itu limbah lemuru yang digunakan diencerkan terlebih dahulu menggunakan air bersih karena diperkirakan kandungan protein yang sangat tinggi didalamnya (Tabel 1), serta limbah yang digunakan pun akan dilakukan uji kadar protein terlebih dahulu sebelum dilakukan pembuatan nata de fish.

\section{Rancangan Penelitian}

Pembuatan nata de fish dilakukan secara uji eksperimental skala laboratorium, terdapat 10 perlakuan yang berbeda yang mebandingkan pemberian bibit Acetobacter xylinum serta perbandingan antara limbah lemuru dan air bersih. Setelah nata de fish yang terbentuk secara sempurna, dilakukan uji proksimat (protein, lemak, karbohidrat, serat dan mineral). Analisis yang digunakan adalah analisis deskriptif. Berikut adalah rancangan penelitian yang dilakukan.

Tabel 1. Rancangan Penelitian Formulasi Pembuatan Nata De Fish

\begin{tabular}{|c|c|c|}
\hline No & Perlakuan & Ket \\
\hline 1 & P1 A (15\% bibit + (1: 10)) & $1 \mathrm{~L}$ air bersih : $100 \mathrm{~mL}$ air limbah \\
\hline 2 & P1 B (15\% bibit + (1: 15)) & $1 \mathrm{~L}$ air bersih : $66 \mathrm{~mL}$ air limbah \\
\hline 3 & P1 C (15\% bibit + (1:20)) & $1 \mathrm{~L}$ air bersih : $50 \mathrm{~mL}$ air limbah \\
\hline 4 & P1 D (15\% bibit + (1:25)) & $1 \mathrm{~L}$ air bersih : $40 \mathrm{~mL}$ air limbah \\
\hline 5 & P1 E (15\% bibit + (1 : 30)) & $1 \mathrm{~L}$ air bersih : $33 \mathrm{~mL}$ air limbah \\
\hline 6 & P2 A (10\% bibit + (1: 10)) & $1 \mathrm{~L}$ air bersih : $100 \mathrm{~mL}$ air limbah \\
\hline 7 & P2 B (10\% bibit + (1: 15)) & $1 \mathrm{~L}$ air bersih : $66 \mathrm{~mL}$ air limbah \\
\hline 8 & P2 C (10\% bibit $+(1: 20))$ & $1 \mathrm{~L}$ air bersih : $50 \mathrm{~mL}$ air limbah \\
\hline 9 & P2 D (10\% bibit + (1: 25)) & $1 \mathrm{~L}$ air bersih : $40 \mathrm{~mL}$ air limbah \\
\hline 10 & P2 E (10\% bibit + (1 : 30)) & $1 \mathrm{~L}$ air bersih : $33 \mathrm{~mL}$ air limbah \\
\hline
\end{tabular}




\section{Proses Fermentasi dan Pasca Panen}

- Loyang yang akan digunakan sebagai wadah media fermentasi dibersihkan terlebih dahulu dan disterilisasi.

- Media fermentasi diantaranya limbah ikan lemuru yang telah diencerkan (sesuai dengan rancangan yang telah ditentukan, dapat dilihat pada Tabel 1) dimasukkan kedalam panci untuk direbus, kemudian masukkan gula sebanyak $200 \mathrm{gr}$, cuka sebanyak $\pm 25 \mathrm{~mL}$ biarkan hingga mendidih. Setelah mendidih, tuang kedalam loyang plastik dan tunggu hingga mendingin, kemudian tuang bibit $A$. xylinum sebanyak 10 atau 15\%. Setelah itu Loyang ditutup dengan koran bersih dan diikat menggunakan karet gelang. Selanjutnya media dalam loyang difermentasi di ruang gelap yang tertutup selama 7-12 hari dalam suhu ruang.

- Pascapanen dilakukan setelah 7-12 hari fermentasi, lapisan atau lembaran nata de fish yang terbentuk dibagian atas diangkat dan dicuci dengan air bersih mengalir. Setelah dicuci, kemudian direbus selama 10 menit untuk mengurangi bau asam nata de fish.

- Nata yang sudah direbus, selanjutnya dipotong-potong dalam bentuk kubus dengan ukuran $1 \times 1 \mathrm{~cm}$ dan direndam dalam air bersih selama 3 hari. Air rendaman setiap hari harus diganti agar bau dan rasa asam hilang. Untuk mengawetkan nata, dapat dengan cara merebus dan menyimpan didalam lemari es. Nata yang telah jadi dapat diolah menjadi produk minuman atau makanan.

\section{Uji Mikrobiologi}

Uji mikrobiologi yang diteliti adalah uji bakteri pathogen pada nata de fsih setelah pasca panen, bakteri yang diuji diantaranya adalah Salmonella spp., Staphylococcus aureus, Escherichia coli. 


\section{HASIL DAN PEMBAHASAN}

Berikut adalah hasil proksimat limbah lemuru yang digunakan :

Tabel 2. Hasil Uji Proksimat Sari lkan yang Digunakan

\begin{tabular}{ccc}
\hline No & Parameter Uji & Hasil Pengujian (\%) \\
\hline 1 & Kadar Lemak & 0.8 \\
2 & Kadar Protein & 44.5 \\
\hline
\end{tabular}

Tingginya kadar protein dibandingkan kadar lemak pada limbah lemuru yang digunakan, dikarenakan produksi limbah yang dihasilkan perusahaan dalam sehari hanya $200 \mathrm{~L}$ dari total produksi ikan lemuru sebanyak 20 ton. Residu limbah yang dihasilkan cukup sedikit dibandingkan produksi yang dibuat, sehingga menyebabkan kandungan protein yang tinggi pada limbah lemuru (Setiyono et al. 2006). Begitu pula aroma dan warna yang dihasilkan, bahwa aroma yang ditimbulkan sangat menyengat dan memiliki warna cokelat pekat.

Proses fermentasi membutuhkan waktu selama 12 hari dan formulasi yang tepat untuk membentuk nata de fish yang sempurna. Berikut adalah hasil nata de fish yang terbentuk:

Tabel 3. Hasil Uji Formula Nata De Fish

\begin{tabular}{cccc}
\hline No & Perlakuan & $\begin{array}{c}\text { Berat Nata } \\
\text { De Fish }\end{array}$ & $\begin{array}{c}\text { Tinggi Nata } \\
\text { De Fish }\end{array}$ \\
\hline 1 & P1 A (15\% bibit + (1: 10)) & $700 \mathrm{gr}$ & $0.8 \mathrm{~cm}$ \\
2 & P1 B (15\% bibit + (1: 15)) & $950 \mathrm{gr}$ & $1.4 \mathrm{~cm}$ \\
$\mathbf{3}$ & P1 C (15\% bibit + (1: 20)) & $\mathbf{9 8 0 ~} \mathbf{~ g r}$ & $\mathbf{1 . 7} \mathbf{~ c m}$ \\
4 & P1 D (15\% bibit + (1:25)) & $\mathbf{7 5 0 \mathrm { gr }}$ & $0.8 \mathrm{~cm}$ \\
5 & P1 E (15\% bibit + (1:30)) & $660 \mathrm{gr}$ & $0.5 \mathrm{~cm}$ \\
6 & P2 A (10\% bibit + (1:10)) & $950 \mathrm{gr}$ & $1.7 \mathrm{~cm}$ \\
7 & P2 B (10\% bibit + (1:15)) & $\mathbf{7 5 0 \mathrm { gr }}$ & $0.7 \mathrm{~cm}$ \\
8 & P2 C (10\% bibit + (1:20)) & $700 \mathrm{gr}$ & $0.6 \mathrm{~cm}$ \\
9 & P2 D (10\% bibit + (1:25)) & $620 \mathrm{gr}$ & $0.6 \mathrm{~cm}$ \\
10 & P2 E (10\% bibit + (1:30)) & $340 \mathrm{gr}$ & $0.4 \mathrm{~cm}$ \\
\hline
\end{tabular}




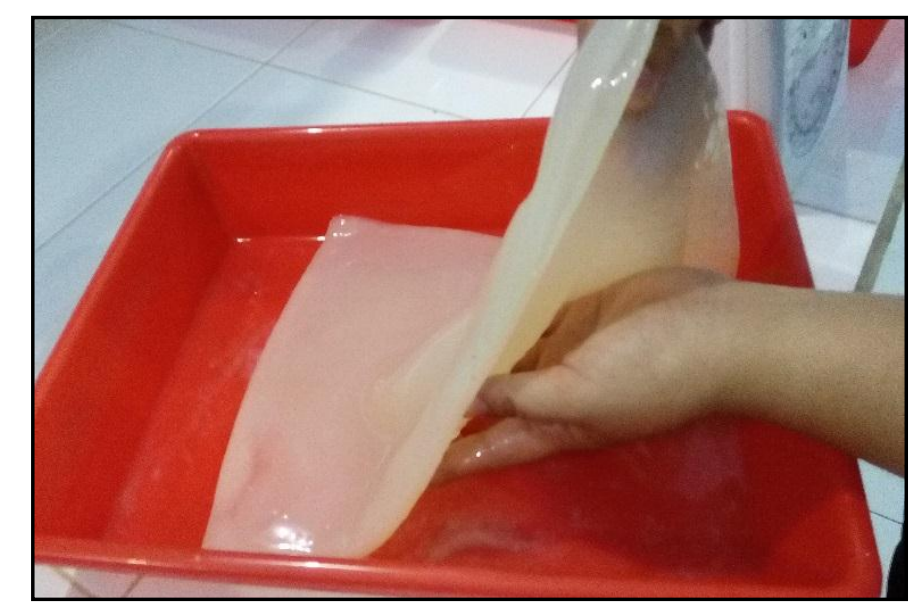

Gambar 1. Formula Nata De Fish Hasil Fermentasi

Loyang yang digunakan sebagai wadah fermentasi nata de fish berukuran 30 $\mathrm{cm}$, nata yang dihasilkan berwarna putih susu dan memiliki aroma tidak sedap berupa amis dan asam yang sangat pekat. Disamping itu, tingginya kandungan protein pada limbah yang digunakan, sehingga pada uji coba perlakuan dilakukan pengenceran dengan air, agar $A$. xylinum tidak terlalu sulit dalam menghidrolisis limbah yang tinggi akan kadar proteinnya. Terlihat pada Tabel 3 , bahwa perlakuan P1C merupakan nata de fish yang terbentuk lebih bagus dibandingkan perlakuan lainnya. Pengenceran yang digunakan yaitu perbandingan air dengan limbah sebesar 1:20 atau setara dengan $1 \mathrm{~L}$ air bersih dengan $50 \mathrm{~mL}$ sari ikan. Kemudian penambahan sumber karbon dengan penambahan gula sebanyak $200 \mathrm{gr}$, sumber nitrogen dengan penambahan urea sebanyak $5 \mathrm{gr}$, dan kondisi yang asam dengan penambahan cuka sebanyak $25 \mathrm{~mL}$ (Kurniawati et al. 2016).

Dalam penelitian ini, nata de fish yang terbentuk diolah kembali menjadi minuman yang menyehatkan. Minuman nata de fish yang diproduksi diberi perasa leci dan dihidangkan dalam kondisi dingin, sedangkan pembuatan sirup nata terdiri dari air sebanyak 1 L, gula sebanyak $200 \mathrm{gr}$, dan perisa leci sebanyak 1 sendok makan, semua bahan pembuatan sirup dimasak diatas kompor hingga matang, kemudian disatukan dengan nata de fish yang telah direbus dan telah hilang bau amis serta asamnya. Berikut adalah gambar proses nata de fish yang dibuat produk minuman, salah satunya adalah pencucian nata (a) dan perebusan nata (b) (Gambar 2), kemudian dilakukan pemotongan nata (gambar 3). 

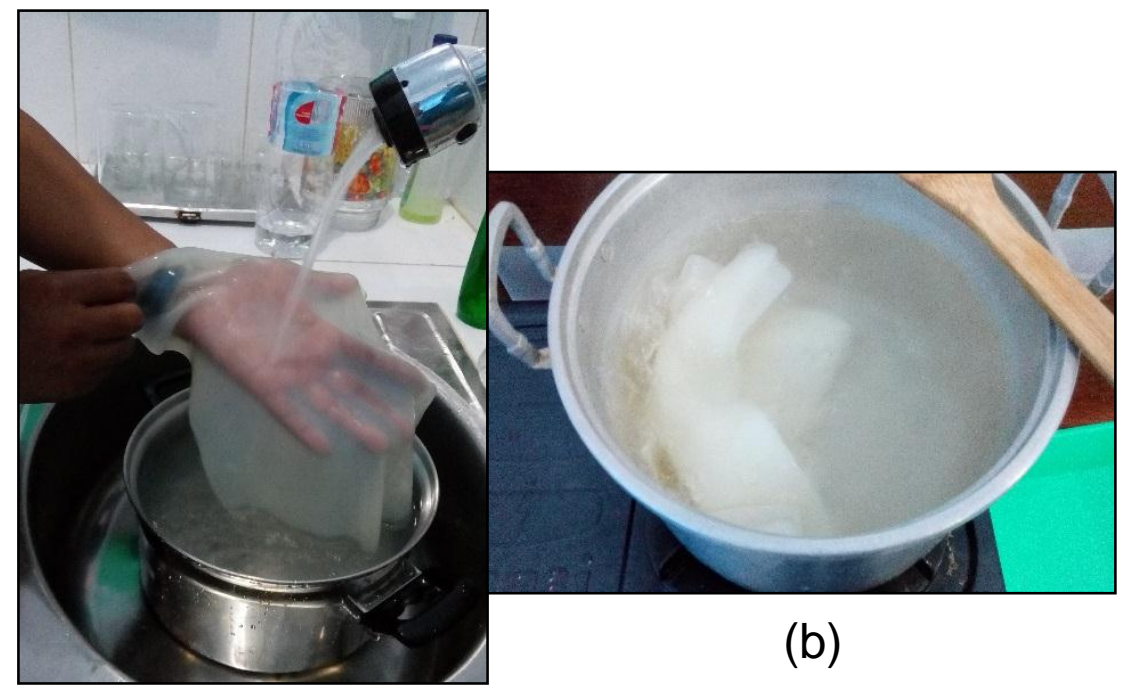

(a)

(b)

Gambar 2. Pencucian nata (a); perebusan nata (b)

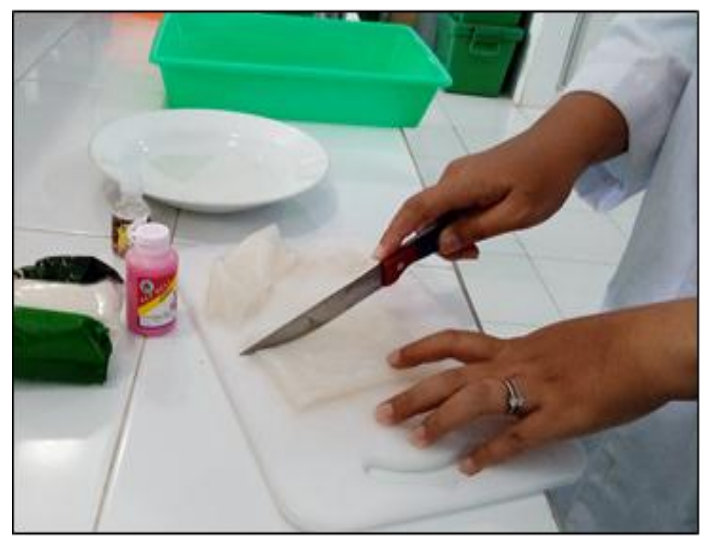

(a)

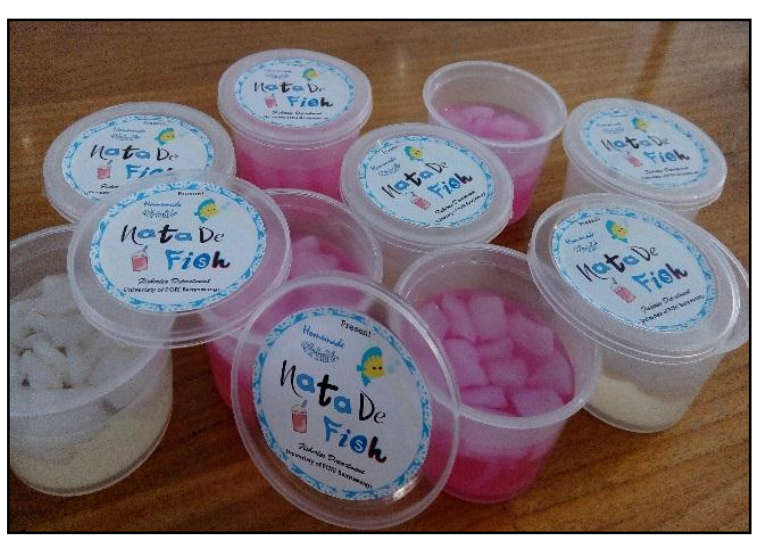

(b)

Gambar 3. Pemotongan Nata De Fish (a); Minuman Nata De Fish (b)

Hasil uji proksimat tersaji pada Tabel 4. dan uji deteksi bakteri pathogen diantaranya deteksi Escherichia coli, Staphylococcus aureus, dan Salmonella spp. Tersaji pada Tabel 5. Berikut adalah hasil uji proksimat nata de fish dan uji bakteri pathoden yang telah dilakukan : 
Tabel 4. Hasil Uji Proksimat Nata De Fish

\begin{tabular}{ccccc}
\hline No & Parameter Uji & Hasil Pengujian & Satuan Unit & Metode Pengujian \\
\hline 1 & Karbohidrat & 73 & \% per $50 \mathrm{gr}$ & SNI ISO 11292:2015 \\
2 & Lemak & 8.25 & \% per $50 \mathrm{gr}$ & SNI.01-2354.3-2006 \\
3 & Protein & 26.75 & $\%$ per $50 \mathrm{gr}$ & SNI.01-2354.4-2006 \\
4 & Serat & 28.5 & \% per $50 \mathrm{gr}$ & SNI.01-2354.1-4006 \\
5 & Nitrogen & 4.3 & \% per $50 \mathrm{gr}$ & SNI.01-2354.4-5006 \\
6 & Mineral & 9.25 & \% per $50 \mathrm{gr}$ & SNI.01-2354.1-6006 \\
\hline
\end{tabular}

Analisis proksimat pada nata de fish memiliki manfaat sebagai penilaian kualitas bahan pangan terutama pada standar zat makanan yang seharusnya terkandung didalam nata. Terlihat bahwa kadar karbohidrat merupakan kandungan tertinggi dalam nata de fish yaitu sebesar $73 \%$, kemudian kandungan serat dan protein pun memiliki nilai yang cukup tinggi yaitu masingmasing sebesar $28.5 \%$ dan $26.75 \%$. Tingginya tiga komponen utama tersebut (karbohidrat, protein, serat) dikarenakan peran $A$. xylinum dan limbah lemuru sebagai sumber utama pembuatan nata. Gula sebagai karbohidrat berperan sebagai sumber karbon dimana $A$. xylinum menghasilkan enzim ekstraseluler menjadi ribuan rantai (homopolimer) serat atau selulosa (Winarno, 1980). Peran ikan lemuru pun menjadi sumber utama tingginya kandungan karbohidrat, protein dan lemak pada nata de fish, informasi yang di dapat dari Badan Ketahan Pangan dan Penyuluhan Yogyakarta, bahwa protein yang terdapat dalam ikan lemuru sebesar $20 \mathrm{~g}$ dalam 112 kalori.

Jika dibandingkan dengan nata de coco, nata de fish memiliki kandungan karbohidrat, lemak, protein yang lebih tinggi dibandingkan nata de coco. Informasi yang didapat dari Puslitbang Biologi LIPI bahwa kandungan nata de coco per 100 gr memiliki kandungan sebesar 20 gr karbohidrat, 20 gr lemak, 12 mg protein. Informasi komposisi kandungan nata de coco tersebut, menjadi landasan bahwa nata de fish memiliki kandungan proksimat yang lebih sehingga memiliki manfaat yang baik untuk tubuh.

Uji bakteri pathogen sangat dibutuhkan karena pembuatan nata de fish menggunakan metode fermentasi yang dilakukan dengan bantuan bakteri asam laktat, olahan pangan yang berasal dari limbah ikan yang didapat berasal dari buangan proses akhir perusahaan industri, yang dimungkinkan adanya bakteri patogen yang berasal dari sumbernya.

Kasus keracunan produk perikanan sering terjadi akibat mengkonsumsi makanan yang terkontaminasi, baik oleh mikroba pathogen penyebab infeksi maupun mikroba penghasil toksin (intoksikasi). Beberapa spesies bakteri pathogen yang sering ditemukan pada produk perikanan antara lain : 
Escherichia coli, Staphylococcus aureus, dan Salmonella spp. (Novotny et al. 2004). Ketiga spesies bakteri pathogen tersebut jika terdapat didalam produk pangan dan termakan oleh manusia akan menyebabkan sakit perut, mata merah, pusing, perut mual, muntah-muntah, bahkan hingga kematian (Anon, 2008). Oleh sebab itu, dalam penelitian ini dilakukan uji deteksi bakteri patoghen pada nata de fish, berikut adalah hasil uji deteksi bakteri pathogen pada nata de fish :

Tabel 5. Hasil Uji Deteksi Bakteri Pathogen Nata De Fish

\begin{tabular}{llllll}
\hline No & Parameter Uji & $\begin{array}{l}\text { Hasil } \\
\text { Pengujian }\end{array}$ & $\begin{array}{l}\text { Batas } \\
\text { Standar }\end{array}$ & $\begin{array}{l}\text { Satuan } \\
\text { Unit }\end{array}$ & Metode Pengujian \\
\hline 1 & Escherichia coli & $<2$ & $<2$ & APM/gr & SNI.01-2332.1.2006 \\
2 & $\begin{array}{l}\text { Salmonella spp. } \\
3\end{array}$ & Negative & Positive & Per 25 gr & SNI.01-2332.2.2006 \\
$\begin{array}{l}\text { Staphylococcus } \\
\text { aureus }\end{array}$ & $<10$ & $10^{3}$ & Colony/gr & SNI.01-2332.9.2011 \\
\hline
\end{tabular}

Ket : APM = Angka Paling Mungkin atau setara MPN = Most Probable Number

Dari hasil deteksi bakteri pathogen yang telah diuji bahwa didalam nata de fish tidak menunjukkan adanya ancaman bahaya bila dikonsumsi. Terlihat dari Tabel 5. ditemukaannya $E$. coli sebanyak $<2$ APM/gr, dimana ambang batas $E$. coli dalam produk pangan menurut standar SNI Tahun 2006 sebesar $<2$ MPN/gr. Keberadaan Salmonella spp. tidak terdeteksi pada nata de fish, sedangkan terdeteksinya $S$. aureus sebanyak $<10$ tidak menunjukkan bahaya pathogen pada nata tersebut dikarenakan ambang batas $S$. aureus menurut standar SNI Tahun 2011 sebesar $10^{3}$ colony/gr atau setara dengan 1000 colony/gr.

\section{KESIMPULAN}

Pemanfaatan limbah lemuru dalam penelitian ini memberikan dampak positif terhadap upaya meminimalisir pencemaran dengan membuat suatu kreativitas olahan produk perikanan yaitu nata de fish, diisisi lain mendukung prinsip blue economy. Kandungan proksimat (protein, lemak, karbohidrat, dan serat) yang lebih baik dibandingkan nata de coco serta tidak ditemukannya bakteri pathogen pada nata de fish, menjadikan nata de fish sebagai dietary fiber yang sangat cocok dan aman dikosumsi oleh semua kalangan, khususnya di Kecamatan Muncar, Kabupaten Banyuwangi.

\section{TERIMA KASIH}

Penulis mengucapkan terima kasih kepada BAPPEDA Kabupaten Banyuwangi atas dana hibah yang diberikan untuk dapat melaksanakan penelitian ini. 


\section{DAFTAR PUSTAKA}

Kurniawati, A., Adharani, N., Sulistiono., Wardhana, MG. 2016. Pemanfaatan Sari Ikan Lemuru Sebagai Bahan Baku Nata De Fish. Laporan Akhir Penelitian BAPPEDA Kabupaten Banyuwangi. Banyuwangi.

Novotny, L., Dvorska, L., Lorencova, A., Beran, V. Pavlik, I. 2004. Fish: a potential source of bacterial pathogens for human beings. Vet. Med. Czech, 49,(9): 343-359.

Pambayun, R. 2002. Teknologi Pengolahan Nata de Coco. Kanisius. Yogyakarta.

Priambodo, Guntur. "Technical and Social Impacts of Wastewater From Fish Processing Industry in Kota Muncar of Indonesia". Surabaya: Department of Environmental Engineering Sepuluh Nopember Institute of Technology (2011).

Purwaningsih, R. 2015. Analisis Nilai Tambah Produk Perikanan Lemuru Pelabuhan Muncar Banyuwangi. Jurnal IImiah Teknik Industri. 14 (1) : 13-23

Setiyono, S. Yudo, "Laporan Akhir Prototipe Alat Pengolah Limbah Industri Pengolahan Ikan di Muncar, Kab. Banyuwangi", BPPT, 2006.

Winarno, F.G., dkk. 1980. Pengantar Teknologi Pangan. Gramedia, Jakarta. 